\title{
$\mathrm{ECF}$ 漂白での N 材パルプとユーカリパルプの比較
}

\author{
エカケミカルス怢式会社 ○レナート・ミューラー, ジリ・バス夕， \\ リレモア・ホルティンジャー, ゲルト・ヴェーン

\section{ECF Bleaching of Softwood and Eucalyptus Pulps - a Comparative Study}

OLennart Meuller, Jiri Basta, Lillemor Holtinger and Gerd Wäne

Eka Chemicals AB (Sweden)

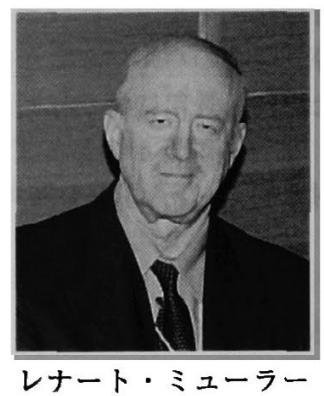

This paper deals with a comparison in ECF bleaching and effluent characterisation of kraft pulps based on softwood and eucalyptus. The study is made for both conventional and oxygen delignified pulps.

There are similarities in the bleaching of softwood and eucalyptus looking at the bleaching parameters. In mill scale there are however normally differences in the number of bleaching stages for conventional and oxygen delignified pulps when bleaching to $90 \%$ ISO brightness. Conventional pulps are mainly bleached in a five stages sequence with peroxide reinforcement in the alkaline stages. $D$ (EOP) D (EP) D. Oxygen delignified pulps are mainly bleached in a four stages sequence. D (EOP) DD, especially softwood pulps. A three or four stages sequence. $\mathrm{D}$ (EOP) DD or $\mathrm{D}$ (EOP) D. is usually used when bleaching oxygen delignified eucalyptus pulps. For brightness levels of $88 \%$ ISO a three stages sequence can be used for both oxygen delignified softwood and eucalyptus pulps.

In the ECF bleaching optimisation study we have used a five stages sequence for all pulps. The same bleaching sequence was used in the effluent characterisation study except for the oxygen delignified eucalyptus pulp where a three stages sequence was used.

Combined effluents from all bleaching stages were characterised and exposed to biological treatment. Characterisation studies were carried out both prior to and after the biological treatment.

The characterisation of the main COD components ; lignin, carbohydrates, methanol, low molecular acids and extractives prior to and after external treatment, corresponded well with the calculation of the total organic composition. The results showed that the organic composition varies for effluents from different pulps.

The COD composition of softwood and eucalyptus effluents were significantly different, which explains why the effluents from the eucalyptus pulps were more biodegradable.

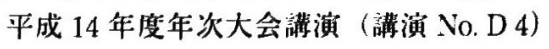


Keywords : Bleaching, ECF, softwood, eucalyptus, COD, AOX, Effluent characterization

分類： $\mathrm{K}_{12}$ 無塩素漂白, $\mathrm{R}_{4}$ クラフトパルプ

\section{1.はじめに}

この報文では ECF 漂白及び排水性状について N 材 パルプとユーカリパルブとを比較する。検討は酸素を 使用しないパルプ及び酸素で前処理したパルプの両方 について行った。

漂白パラメーターを見ると $\mathrm{N}$ 材パルプとユーカリ パルプで類似性がある。しかし $90 \%$ ISO 白色度での 操業では酸素を使用しないパルプと酸素で前処理した パルプとでは一般に漂白段数に違いがある。酸素を使 用しないパルプでは主としてアルカリ段で過酸化水素 補強する 5 段シーケンス， D(EOP) D (EP)Dである。 酸素で前処理したバルプ，特に $\mathrm{N}$ 材パルブ，では主 として 4 段シーケンス， D(EOP) DD である。酸素で 前処理したユーカリパルブでは 3 もしく 4 段シーケ ンス， $\mathrm{D}$ (EOP) $\mathrm{DD}$ もしくは $\mathrm{D}(\mathrm{EOP}) \mathrm{D}$ が通常使用さ れる。

$88 \%$ ISO 白色度での操莱では酸素で前処理した N 材パルプ及び酸素で前処理したユーカリパルプの両方 に 3 段シーケンスを使用することができる。

ECF 漂白の最畄化の検討ではすべてのパルプにつ いて 5 段シーケンスを使用し，また排水性状の検討で も同様の漂白シーケンスを使用した。但し酸素で前処 理したユーカリパルブについては 3 段シーケンスで漂 白した。全ての漂白段からの排水を全部一楮にした排 水 (コンバインド排水) の生化学処理を行い処理前後 の性状を調べた。

CODの主要成分である, リタニン, 炭水化物, メ タノール, 低分子の酸及び抽出物, の外部処理前後の
性状は全有機成分の計算值とよく一致した。その結果, 排水中の有機成分はパルプの種類によって変動するこ とがわかった。排水中の COD 組成は $\mathrm{N}$ 材パルブと工 一カリパルプでは相当違っており，このことからなぜ ユーカリパルプからの排水がより容易に生分解される かを説明できた。

\section{2. ラボでの ECF 漂白}

ECF ラボ漂白は酸素を使用しない $\mathrm{N}$ 材及びユーカ リパルブと, 酸素で前処理した $\mathrm{N}$ 材及びユーカリパ ルプの両方について実施した。未唒しパルプ性状と 薬品添加量を表 1 に示す。二酸化塩素添加量は活性塩 素として計算した。パルプは最適な漂白条件 ${ }^{1.231}$ を使 用し，かつ代表的なう段シーケンスを使用して最終白 色度が $89 \%$ ISO 以上になるように漂白した。

\section{3. 適切な漂白条件の評価}

$\mathrm{ECF}$ 漂白シーケンス各段での適切な漂白条件を検 討するため, 全段の最終 $\mathrm{pH}$ の重要性に力点を置いて 実験を行った。最終 $\mathrm{pH}$ はかなり容易に調整でき，か つパルブ及び排水の性状に影響を与える因子の一つと 考えられる。D段の各 $\mathrm{pH} レ$ レ゙で残留塩素レベルを $0.5 \mathrm{~kg} / \mathrm{t}$ 以下に保つように時間と温度を調整した。

\subsection{D $\Phi$ 段における最終 $\mathrm{pH}$ の効果}

EO段の条件を一定にしてD $\Phi$ 段での最終 $\mathrm{pH}$ を変 化させたときの効果を評価した。

酸素を使用しないN 材及びユーカリパルプに関し

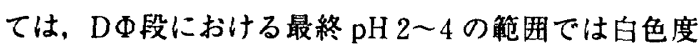
もしくはカッパー価のどちらにも顕著な効果は見られ

表 1 Unbleached pulp characteristics, bleaching sequences and chemical charges

\begin{tabular}{l|c|c|c|c}
\hline \multicolumn{1}{c|}{ Kraft Pulp } & $\begin{array}{c}\text { Conventional } \\
\text { Softwood }\end{array}$ & $\begin{array}{c}\mathrm{O}_{2} \text { del. } \\
\text { Softwood }\end{array}$ & $\begin{array}{c}\text { Conventional } \\
\text { Eucalyptus }\end{array}$ & $\begin{array}{c}\mathrm{O}_{2} \text { del. } \\
\text { Eucalyptus }\end{array}$ \\
\hline Kappa No & 28 & 12 & 13 & 8 \\
\hline Brightness, \% ISO & 22 & 38 & 42 & 56 \\
\hline Viscosity. $\mathrm{dm}^{3} / \mathrm{kg}$ & 996 & 1,000 & 1,127 & 993 \\
\hline $\mathrm{Bl}$. Sequence & $\mathrm{D}(\mathrm{EPO}) \mathrm{D}(\mathrm{EP}) \mathrm{D}$ & $\mathrm{D}(\mathrm{EPO}) \mathrm{D}(\mathrm{EP}) \mathrm{D}$ & $\mathrm{D}(\mathrm{EO}) \mathrm{D}(\mathrm{EP}) \mathrm{D}$ & $\mathrm{D}(\mathrm{EO}) \mathrm{D}(\mathrm{EP}) \mathrm{D}$ \\
\hline $\mathrm{ClO}_{2}(\mathrm{aCl}), \mathrm{kg} / \mathrm{t}$ & 86 & 39 & 45 & 25 \\
\hline $\mathrm{Kappa} \mathrm{factor}^{\mathrm{H}_{2} \mathrm{O}_{2}, \mathrm{~kg} / \mathrm{t}}$ & 0.20 & 0.15 & 0.15 & 0.15 \\
\hline
\end{tabular}


なかった。EO段での粘度低下を考虑すると D $\Phi$ 段に おける推奖最終 $\mathrm{pH}$ は約 3 である（図 1)。

こうした傾向は酸素で前処理した $\mathrm{N}$ 材及びユーカ リパルブに関しても同様である。ただし EO段での粘 度低下はより高い最終 $\mathrm{pH}$ 約 3.5 で起こる（図 2)。

\subsection{EO 段における最終 $\mathrm{pH}$ の効果}

酸素を使用しないN 材及びユーカリパルプについ て EO段での最終 $\mathrm{pH}$ の効果を見ると, 最終 $\mathrm{pH}$ 9 12 の範囲で白色度が連続的に増加し（特にユーカリ）, かつカッパー価が诚少し, 粘度の低下は非常に限られ

\section{Conventional Pulp}

Softwood, Eucalyptus

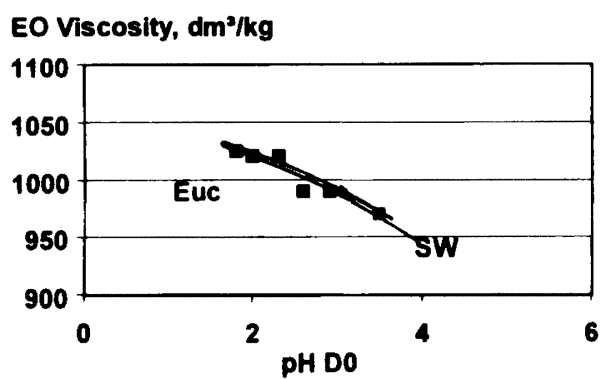

るという効果が見られた（図 3)。

こうした効果は酸素で前処理した $\mathrm{N}$ 材及びユーカ リパルプに関してもほほ同様であった（図 4)。

$\mathrm{EO}$ 段での最終 $\mathrm{pH}$ の効果を COD 形成についても 検討した。排水中の COD レベルも EO 段での最適最 終 $\mathrm{pH}$ を決める因子になる。図 5 を見ると，不必要な $\mathrm{COD}$ が形成される $\mathrm{pH} 11$ 以上にする理由はないよう である。N材とユーカリパルプでは COD レベルが異 なっており，これは未晒しカッパー価の違いに関係し ている。

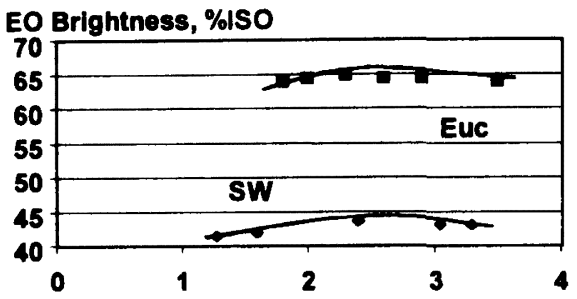

EO Kappa Number

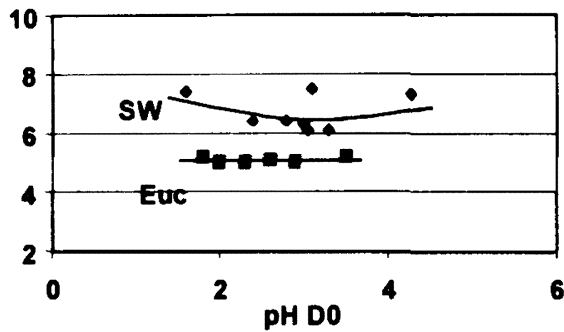

図 1 Effects in the EO stage related to final $\mathrm{pH}$ in $\mathrm{D} \Phi$ stage-coventional pulp

Oxygen delignified pulp

Softwood, Eucalyptus

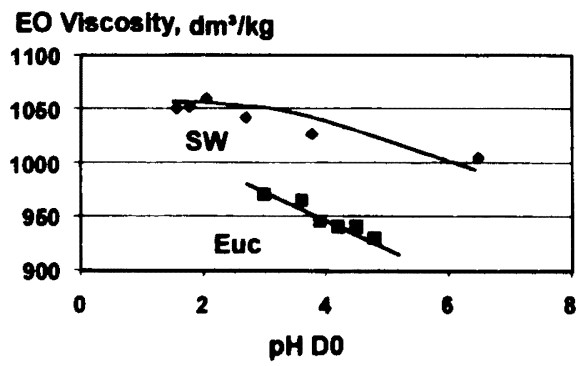

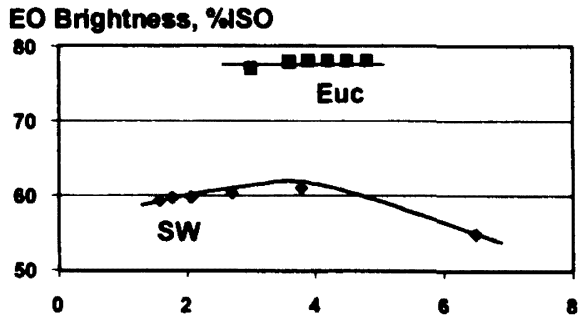

EO Kappa Number

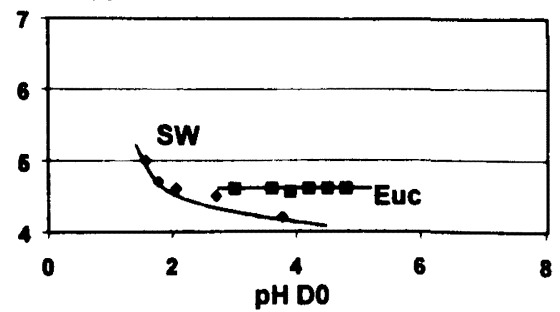

图 2 Effects in the EO stage related to final $\mathrm{pH}$ in $\mathrm{D} \Phi$ stage-oxygen delignified pulp 
3.3 D 1 段における最終 $\mathrm{pH}$ の効果

酸素を使用しない $\mathrm{N}$ 材及びューカリパルプについ てD 1 段での最終 $\mathrm{pH}$ の効果を見ると，一定の二酸化 塩素供給量では白色度への効果は限られている。しか し粘度は最終 $\mathrm{pH}$ の上昇に伴って低下する傾向がある (図6)。

酸素で前処理した $\mathrm{N}$ 材及びユーカリパルプの場合

Conventional pulp

Softwood, Eucalyptus

\section{Brightness \% ISO}

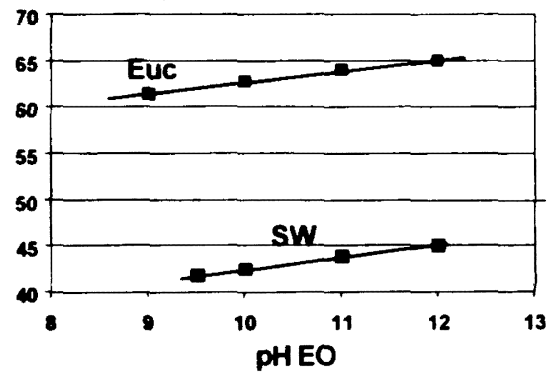

は最終 $\mathrm{pH}$ の上昇に伴って白色度は増加した。ここで は最適最終 $\mathrm{pH}$ は粘度によって決まり， N 材及びュー カリパルブ共 $\mathrm{pH} 3.0$ 3.2である（図7）。他のラボ テスト結果から我々は D 1 段での最適最終 $\mathrm{pH}$ は二酸 化塩素供給量によって異なるという知見を得ている。

\subsection{E 2 段における最終 $\mathrm{pH}$ の効果}

過酸化水素で補強された E 2 段では白色度，粘度共

\section{Viscosity $\mathrm{dm}^{2} / \mathrm{kg}$}

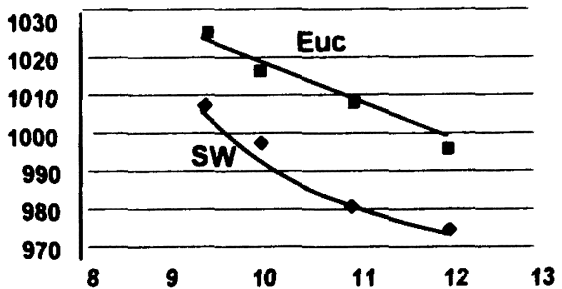

Kappa No

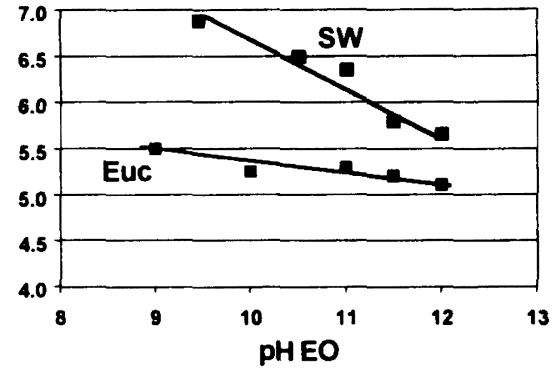

図 3 Effects of final pH on pulp characteristics in the EO-stage-coventional pulp

\section{Oxygen delignified pulp}

\section{Softwood, Eucalyptus}

\section{Brightness \% 150}

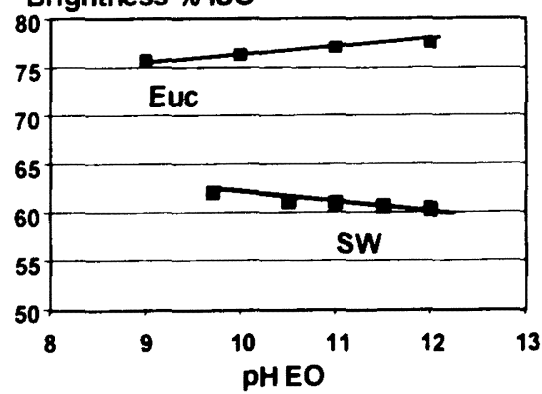

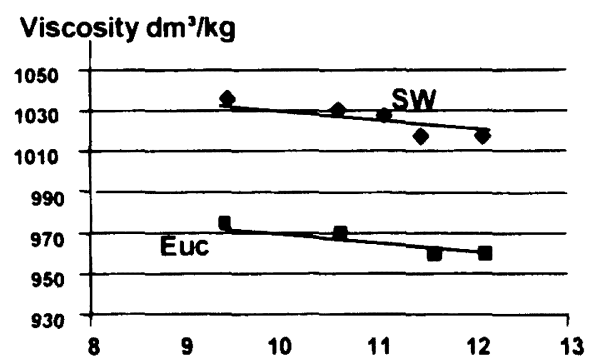

Kappa No

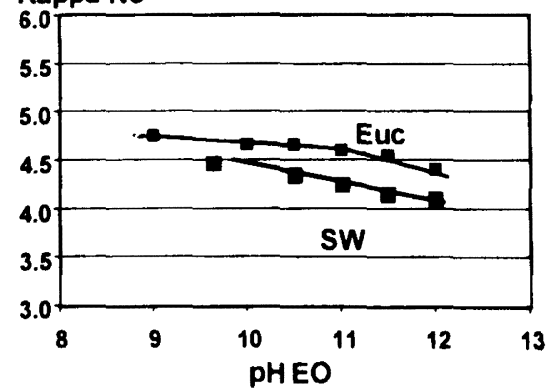

図 4 Effects of final pH on pulp characteristics in the EO-stage-oxy gen delignified pulp 
最終 $\mathrm{pH}$ 上昇によりかなりの影響を受ける。最終 $\mathrm{pH}$ 10 から 11.5 への上昇で酸素を使用しないパルプでは 白色度が 2〜2.5\% ISO 増加する。酸素で前処理した パルプの場合は白色度の增加は小さく $0.6 \sim 1.0 \%$
ISO 程度である。すべてのパルプで最終 $\mathrm{pH}$ 10〜11.5 での粘度低下はわずかである。ただし酸素を使用しな いN 材では最終 $\mathrm{pH}$ が 11.2 を超えると影響が大きく なるようである（図 8,9）。

\section{Conventional pulp}

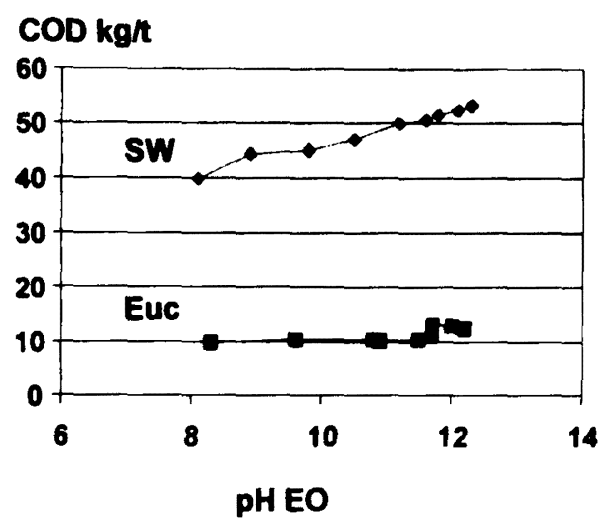

\section{Oxygen delignified pulp}

\section{COD kght}

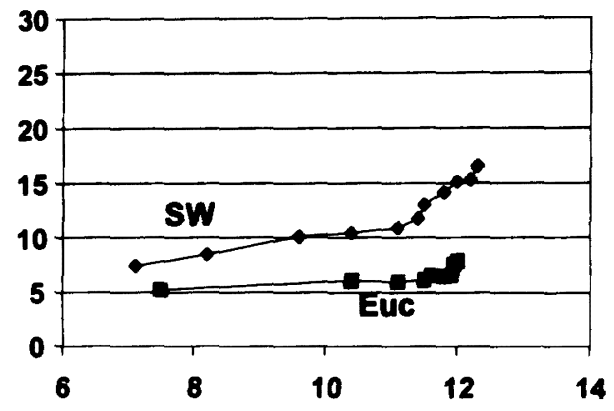

PH EO

図 5 Effects of final $\mathrm{pH}$ on COD formation in the EO stage

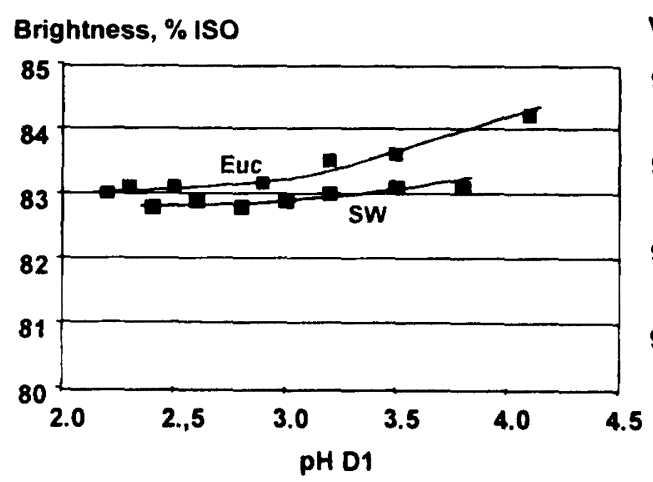

Viscosity $\mathrm{dm}^{3} / \mathbf{k g}$

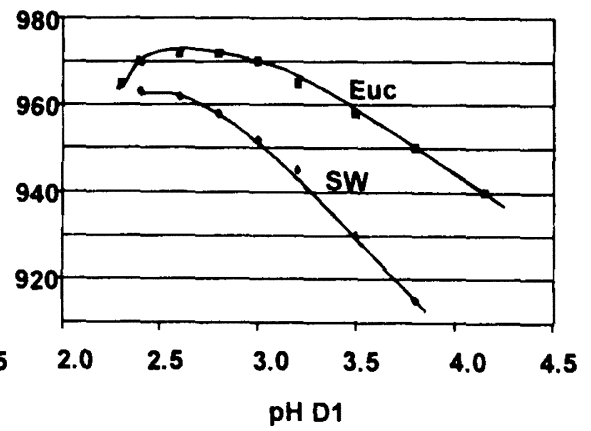

図 6 Brightness and viscosity related to $\mathrm{pH}$ in $\mathrm{D} 1$ stage-coventional pulp

\section{Brightness \% ISO}

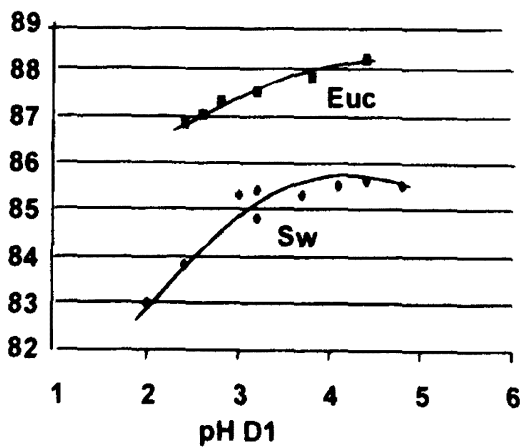

\section{Viscosity $\mathbf{d m}^{\mathbf{3}} / \mathbf{k g}$}

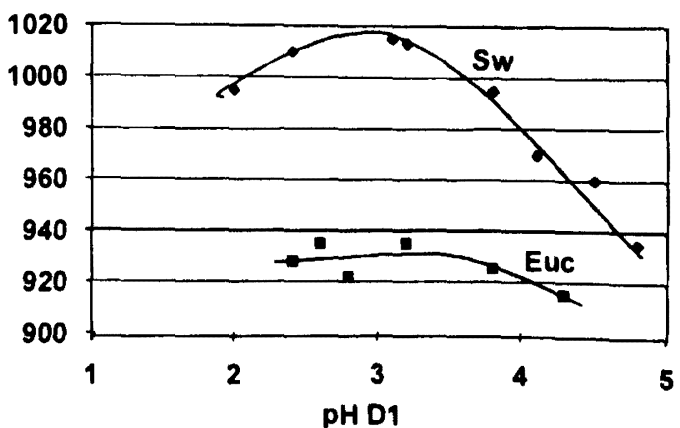

国 7 Brightness and viscosity related to $\mathrm{pH}$ in D 1 stage-oxygen delignified pulp 


\subsection{2 段における最終 $\mathrm{pH}$ の効果}

D 2 段でも白色度と粘度について最終 $\mathrm{pH}$ の効果を 検討した。二酸化塩素供給量は酸素を使用しないパル フの $\mathrm{N}$ 材パルプでは $15 \mathrm{~kg} / \mathrm{t}$ ，ユーカリパルプでは 10 $\mathrm{kg} / \mathrm{t}$ とした。酸素を使用しないパルプでは白色度に ついての最適最終 $\mathrm{pH}$ は $\mathrm{N}$ 材でもユーカリでも同じ であった。最終 $\mathrm{pH} 3$ から 4 のレベルでは粘度の低下 はないかまたはわずかであるが，最終 $\mathrm{pH}$ がそれ以上 高くなると粘度低下は增大する（図 10）。

酸素で前処理したパルプでは白色度についての最適
最終 $\mathrm{pH}$ は $\mathrm{N}$ 材とユーカリでは違っており，また二 酸化塩素供給量によっても異なる。図 11 にユーカリ

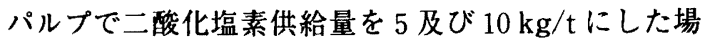
合の結果を示す。ここで $\mathrm{N}$ 材パルプでの二酸化塩素 供給量は $5 \mathrm{~kg} / \mathrm{t}$ であった。粘度については二酸化塩 素供給量が $5 \mathrm{~kg} / \mathrm{t}$ で最終 $\mathrm{pH} 3$ から 4 のレベルでは $\mathrm{N}$ 材及びユーカリパルプ共粘度の低下はない。しかし二 酸化塩素供給量が多くなると，最終 $\mathrm{pH} 4$ 以上での粘 度低下がより顕著になる（図 11）。
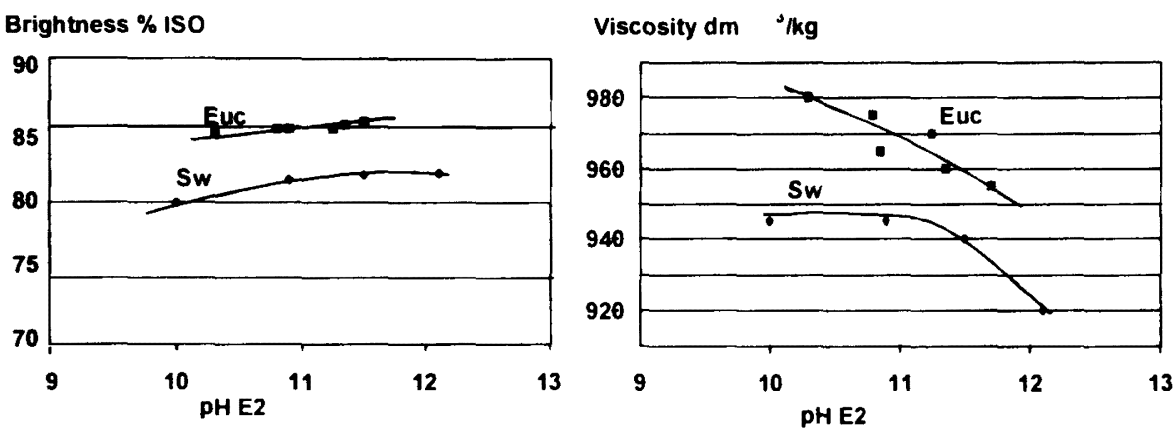

图 8 Brightness and viscosity related to $\mathrm{pH}$ in $\mathrm{E} 2$ stage-coventional pulp

\section{Brightness \% ISO}

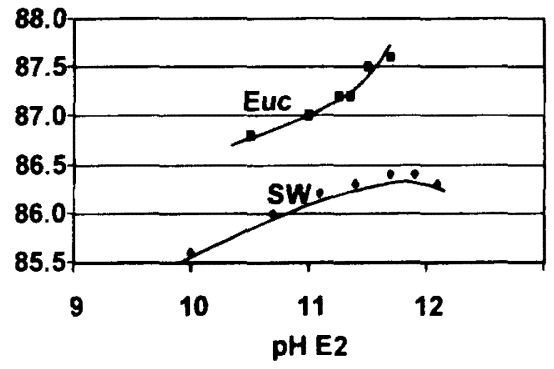

\section{Viscosity $\mathrm{dm}^{3} / \mathbf{k g}$}

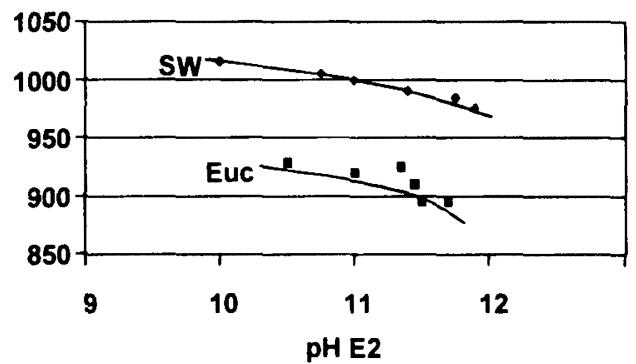

図 9 Brightness and viscosity related to $\mathrm{pH}$ in $\mathrm{E} 2$ stage-oxygen delignified pulp

Brightness, \% 150

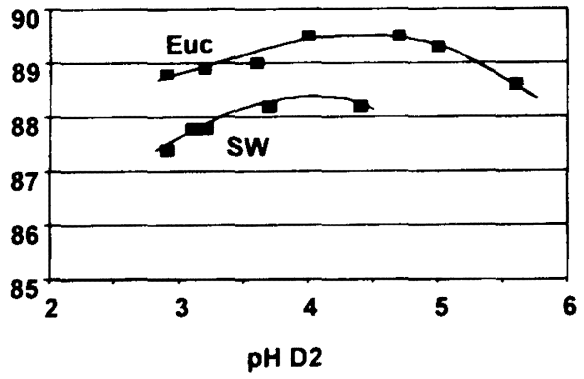

Viscosity $\mathrm{dm}^{3} / \mathrm{kg}$

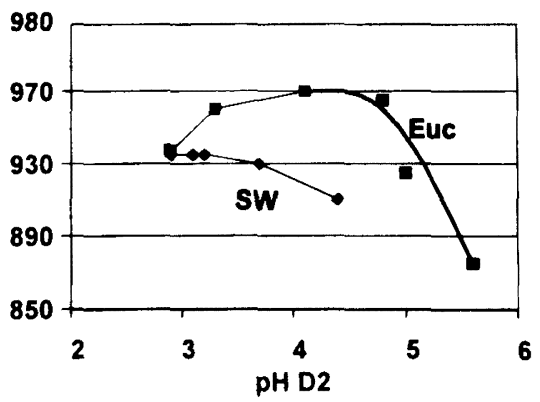

图 10 Brightness and viscosity related to $\mathrm{pH}$ in $\mathrm{D} 2$ stage-coventional pulp 

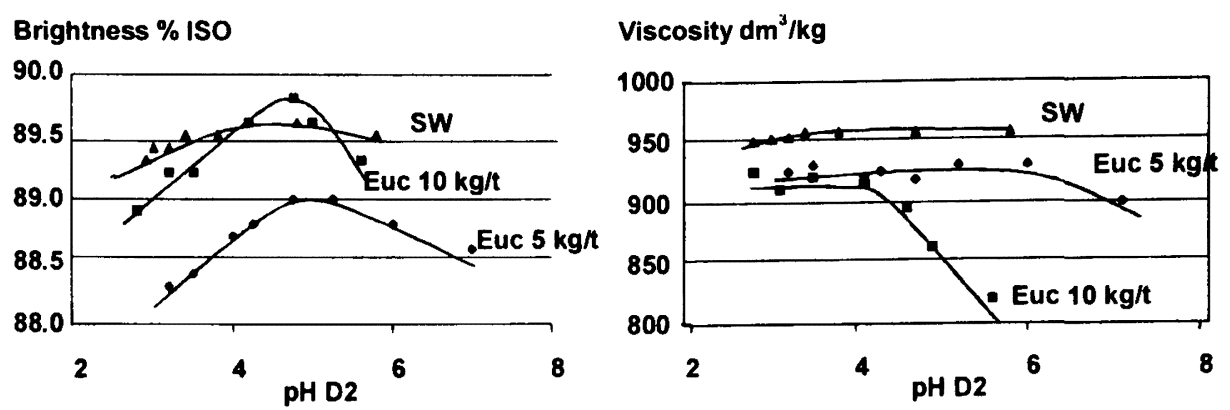

图 11 Brightness and viscosity related to $\mathrm{pH}$ in $\mathrm{D} 2$ stage-oxygen delignified pulp

\section{6 酔しパルプの最終結果}

晒しパルプの最終性状を表 2 に示す。漂白段全てで 最適漂白条件を使用し, 最終白色度は 89〜90\% ISO となった。粘度低下はすべてのパルプで正常で, 最終 カッパー価はすべてのパルプで 0.6 0.8であった。

\section{4. 漂白排水の性状比較}

性状に対する調査は表 1 及び 2 に従ってラボで $\mathrm{ECF}$ 漂白した $\mathrm{N}$ 材及びユーカリパルプから得た排水 について，全部の排水を一緒にしたもの（コンバイン ド排水）について行った。但し酸素で前処理したユー カリパルプについては 3 段シーケンスで最終白色度が 89.5\% ISOになるように漂白しだ。コンバインド排 水は生化学処理を行い処理前後の性状を調べた.5.6.7。
検討したパラメーターは AOX, COD, BOD, 樹脂 酸及びステロールを含む有機物, 無機物, そして Microtox として測定される急性毒性である。生化学処 理後の排水性状調査では緑藻 Selenastrum 及び甲款 類動物の Ceriodaphnia Dubia を使って生物検定も実 施した（表 3)。

ラボでの排水の生化学処理としては図 12 に示すよ うな二段の連続プロセスを使用した。その処理では最 善の分解が得られるように選択したので,これから生 化学処理の可能性を知ることができる。この処理はク ロレート含有分を除去するための一段目の 2 時間の嫌 気性ステージと，COD，AOXなどとして測定される 有機化合物を減らすための最終の 12 時間の好気性活 性污泥ステージからなっている゙”。

表 2 Bleached pulp characteristics

\begin{tabular}{l|c|c|c|c}
\hline \multicolumn{1}{c|}{ Kraft Pulp } & $\begin{array}{c}\text { Conventional } \\
\text { Softwood }\end{array}$ & $\begin{array}{c}\mathrm{O}_{2} \text { del. } \\
\text { Softwood }\end{array}$ & $\begin{array}{c}\text { Conventional } \\
\text { Eucalyptus }\end{array}$ & $\begin{array}{c}\mathrm{O}_{2} \text { del. } \\
\text { Eucalyptus }\end{array}$ \\
\hline Kappa No & 0.8 & 0.6 & 0.8 & 0.8 \\
\hline Brightness, \%ISO & 89.5 & 90.2 & 89.3 & 89.3 \\
\hline Visc. drop. $\mathrm{dm}^{3} / \mathrm{kg}$ & 130 & 115 & 85 & 85 \\
\hline
\end{tabular}

表 3 Parameters studied in the effluents

\begin{tabular}{l|l}
$\begin{array}{c}\text { Combined effluents prior to } \\
\text { Effluent Treatment }\end{array}$ & \multicolumn{1}{|c}{\begin{tabular}{c}
\multicolumn{1}{c}{$\begin{array}{c}\text { Combined effluents after } \\
\text { Effluent Treatment }\end{array}$} \\
\hline AOX, COD, BOD 5, \\
Chlorate and Colour
\end{tabular}} \\
Organics & $\begin{array}{l}\text { AOX, COD, BOD 5 } \\
\text { Chlorate }\end{array}$ \\
Resin acids & Organics \\
Sterols & Resin acids \\
Microtox & Sterols \\
\hline
\end{tabular}




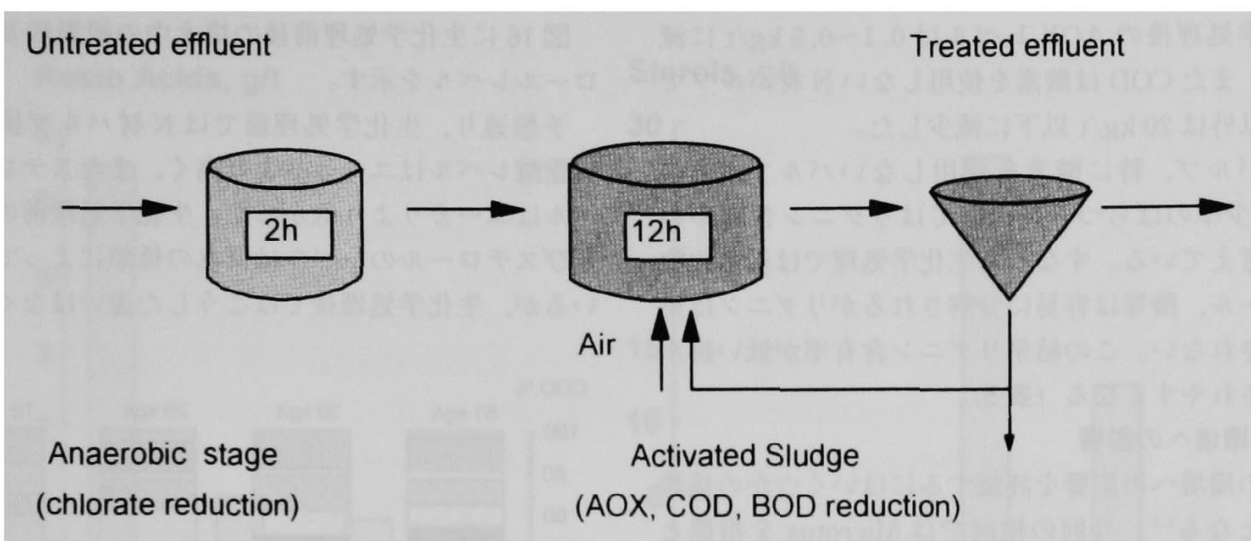

図 12 Laboratory effluent treatment

\section{1 生化学処理前の排水性状}

ユーカリと $\mathrm{N}$ 材パルプの排水を比較してみると， AOX レベルではよく似た結果を示している。どちら のパルプでも AOX レベルは酸素を使用しないパルプ

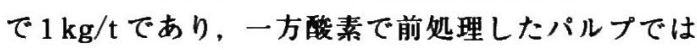
$0.6 \sim 0.7 \mathrm{~kg} / \mathrm{t}$ であった。CODレベルについては当初 のカッパー価に依存する。またBOD 5 および色度に ついても合わせて示す（図 13）。

水溶性有機化合物はさらにリクニン, 炭水化物, メ タノール, 抽出物, 及び種々の低分子量の酸に分け, そしてそれらの全 COD レベルへの影翌を表 4 に示す 換算係数を使って計算した

図 14 に排水中の各成分を CODに換算した後での 割合をパルプ別に示す。棒グラフ上部の数字は全 COD
の実測値である。 $\mathrm{N}$ 材とユーカリパルプの間の最も重 要な違いは， $\mathrm{N}$ 材パルプ排水中のリグニン含有率が高 いということである。ところで， $\mathrm{N}$ 材パルブ排水中の 全 COD レベルは酸素を使用しないパルプでの $61 \mathrm{~kg} /$ $\mathrm{t}$ から酸素で前処理したパルプでの $30 \mathrm{~kg} / \mathrm{t}$ と変動す るが, リグニン, 炭水化物, メタノール, 酸, 及び抽 出物の分布は非常によく似ている。一方酸素で前処理 した $\mathrm{N}$ 材パルプ排水と酸素を使用しないユーカリパ ルプ排水の全 COD レベルはほほ同じであるが, COD 成分の分布はかなり異なっている。

\section{2 生化学処理後の排水性状}

ここでは排水を生化学処理した時の効果についての ベる。図 15 に生化学処理後の AOX 及びCOD レベル を示す。

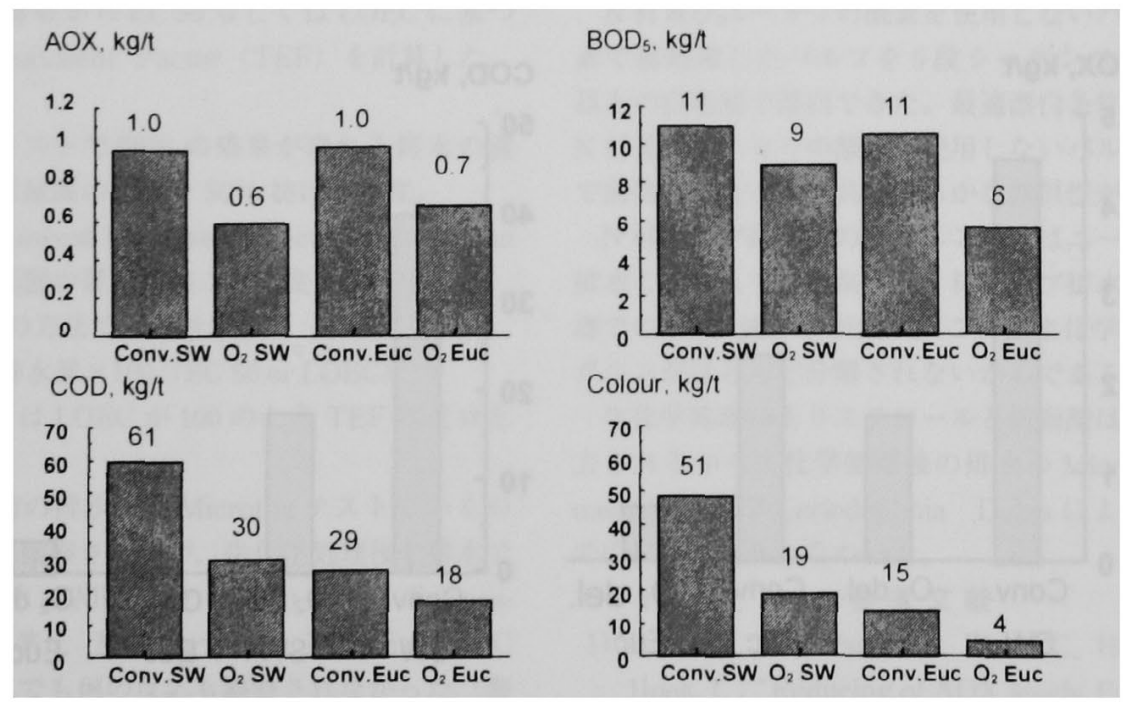

図 13 Effluent characteristics prior to treatment 
生化学処理後の AOX レベルは 0.1〜0.5 kg/t に減 少した。また COD は酸素を使用しない $\mathrm{N}$ 材パルプで の排水以外は $20 \mathrm{~kg} / \mathrm{t}$ 以下に減少した。

$\mathrm{N}$ 材パルプ, 特に酸素を使用しないパルプ, での COD 減少率のばらつきについてはリグニン含有率の 影響と考えている。すなわち生化学处理では炭水化物, メタノール，酸等は容易に分解されるがリグニンは殆 ど分解されない。この結果リグニン含有率が低い排水 が処理されやすくなる (表 5)。

\section{3 環境への影響}

排水の環境への影锌を評価するにはいくつかの係数 が必要となる゙。今回の検討では Microtox を指標と して選んだ:抽出物から生じるステロールや樹脂酸の ような化合物のたとえば魚への影響が疑われることか ら、これらの化合物について環境面での湘定を行った。 また生物検定には緑藻 Selenastrum 及び甲款類動物 の Ceriodaphnia Dubia を使用した。

表 4 Conversion factors used in the COD characterisation

\begin{tabular}{l|c}
\hline \multicolumn{1}{c|}{ Compounds } & Factors* $^{*}$ \\
\hline Lignin & 1.9 \\
Carbohydrates & 1.2 \\
Methanol & 1.5 \\
Formic acid & 0.4 \\
Acetic acid & 1.1 \\
Extractives & 2.7 \\
\hline
\end{tabular}

"from substance to COD

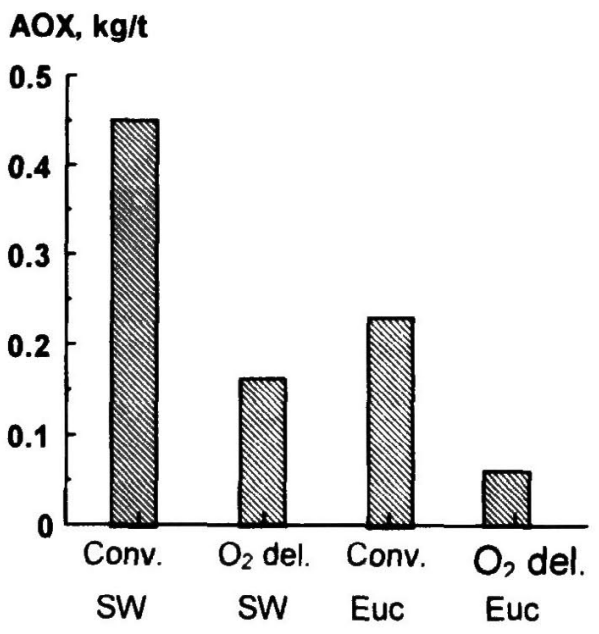

図 16 に生化学処理前後の排水中の樹脂酸及びステ ロールレベルを示す。

予想通り, 生化学処理前では $\mathrm{N}$ 材パルプ排水中の 樹脂酸レベルはユーカリより高く、またステロールレ ベルはユーカリより低かった。生化学処理前の樹脂酸 及びステロールのレベルは排水の種類によって違って いるが, 生化学処理後ではこうした違いはなくなって

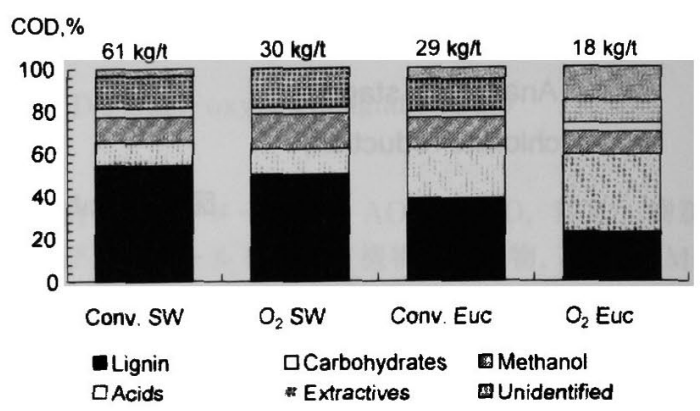

図 14 Effluent COD characteristics prior to treatment-combined effluents

表 5 Reductions in laboratory effluent treatment

\begin{tabular}{l|c}
\hline \multicolumn{1}{c|}{ Compound } & Reduction \\
\hline Lignin & $0-30$ \\
Carbohydrates & $85-100$ \\
Methanol & 100 \\
Acids & 100 \\
Resin Acids & $60-100$ \\
Sterols & $60-100$ \\
\hline
\end{tabular}

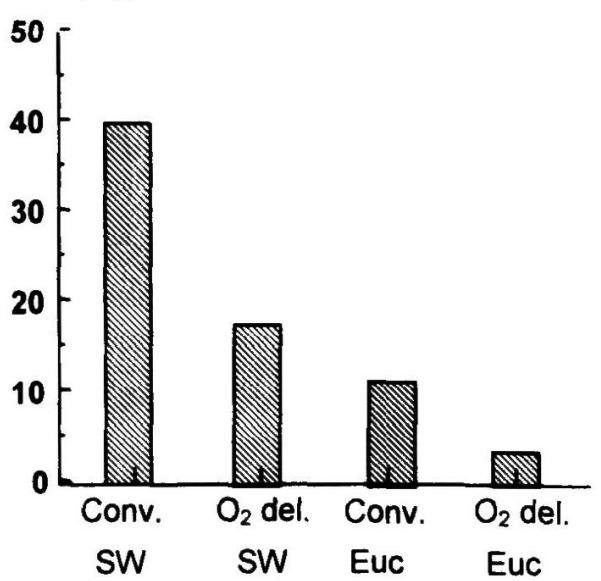

図 15 Levels of AOX and COD after effluent treatment 


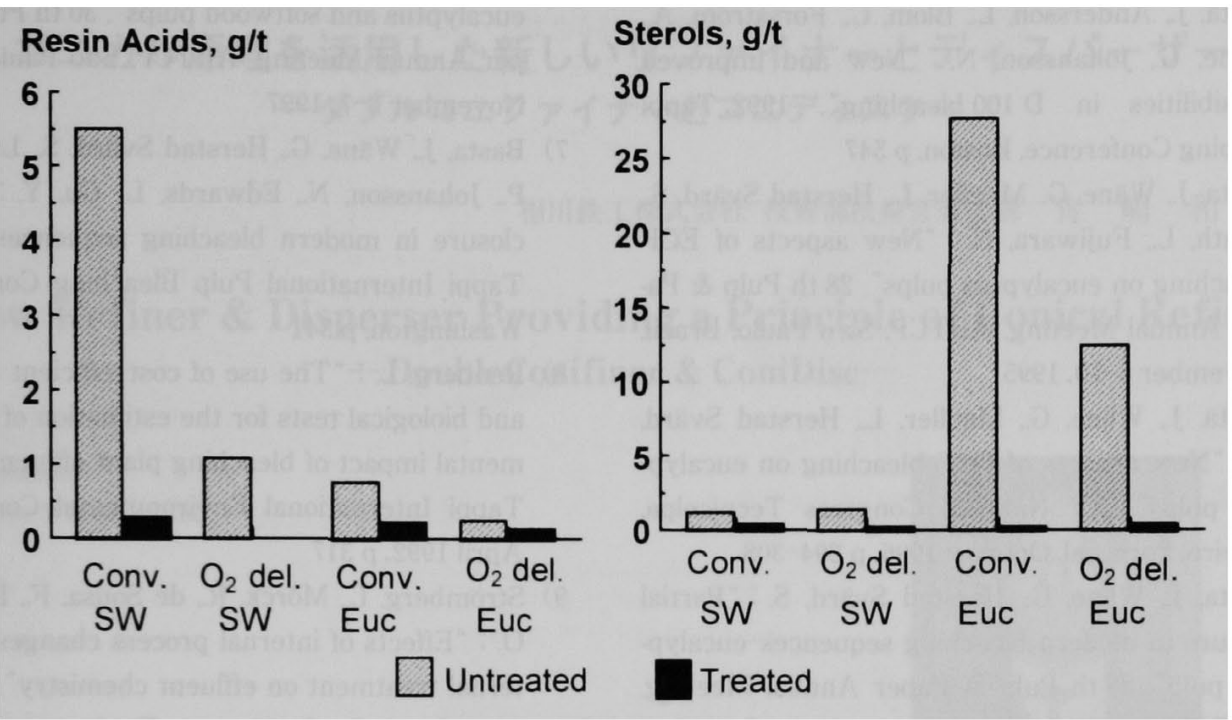

図 16 Levels of resin acids and sterols in combined effluents prior to and after effluent treatment

表 6 Bioassay results after treatment-combined effluents

\begin{tabular}{l|c|c|c|c}
\hline & Conv. SW & $\mathrm{O}_{2} \mathrm{SW}$ & Conv. Euc & $\mathrm{O}_{2}$ Euc \\
\hline Microtox TEF (EC 50) & 0 & 0 & 0 & 0 \\
\hline Selenastrum TEF (EC 50) & 0 & 0 & 0 & 0 \\
\hline Cerio. Dubia Repr. TEF (LOEC) & 0 & N/A & 0 & 0 \\
\hline
\end{tabular}

いる。これは生化学処理により樹脂酸とステロールが ほとんど全部除去されたためである。

生物検定の結果から EC 50 もしくは LOECに基つ いて Toxic Equivalent Factor (TEF) を計算した。

ここで

*EC 50 はテストで $50 \%$ の効果が現れる排水の濃 度。例えば緑藻の生長を $50 \%$ 妨げる濃度。

*LOEC は Lowest Observed Effect Concentration の略で，影響が最初に起こる濃度を意味する。

*TEFは次の方法で計算される。

$\mathrm{TEF}=$ 排水量 $\times 100 /(\mathrm{EC} 50$ or LOEC $)$

EC 50 もしくは LOECが 100 のとき TEFはゼロと 定義される。

生化学处理前の排水では Microtox テストでいくつ か微小な反応が観察されたが, 生化学処理後の排水で はすべての排水で Microtox（EC 50 基準）, Selenastrum (EC 50 基準)，及び Ceriodaphnia Dubia (LOEC 基準)のいずれでも何の反応も観察されなかった（表 6)。

\section{5. 結 論}

$\mathrm{N}$ 材及びユーカリの酸素を使用しないパルプ及び酸 素で前処理したパルプを 5 段シーケンスで $89 \%$ ISO 以上の白色度で漂白できた。最適漂白条件については $\mathrm{N}$ 材及びユーカリの酸素を使用しないパルプ及び酸素 で前処理したパルブ共に明らかな類似性がある。

$\mathrm{N}$ 材パルプ排水中のリグニン濃度はユーカリパルフ 排水と比較して相当高い。 $\mathrm{N}$ 材パルブ排水では排水処 理での COD 減少率が低い。これは生化学处理ではリ クニンがほとんど分解されないからである。

生化学処理によりステロールと樹脂酸はほほ全量除 去されるから生化学処理後の排水の Microtox, Selenastrum, 及びCeriodaphnia Dubiaによる生物検定 での反応は見られなかった。

\section{参考文献}

1) Basta. J., Andersson, L., Blom, C., Holtinger, L. Hook, J. : "Reducing of AOX levels. Part 2 : Chlorine-free bleaching". Appita 45 (1) : 29 (1991) 
2) Basta, J., Andersson, L., Blom, C., Forsström, A., Wäne, G., Johansson, N. : "New and improved possibilities in D 100 bleaching”. 1992, Tappi Pulping Conference, Boston, p 547

3) Basta, J., Wäne, G., Meuller, L., Herstad Svärd, S., Birath, L.. Fujiwara, N. : New aspects of ECF bleaching on eucalyptus pulps". 28 th Pulp \& Paper Annual Meeting. ABTCP, Sào Paulo. Brazil, November 6-10, 1995

4) Basta. J., Wäne, G.. Meuller, L.. Herstad Svärd, S. : "New aspects of ECF bleaching on eucalyptus pulps". XV National Congress Tecnicelpa. Aveiro, Portugal, October 1996, p 294-308

5) Basta, J., Wäne, G., Herstad Svärd, S. : “Partial closure in modern bleaching sequences-eucalyptus pulp". 29 th Pulp \& Paper Annual Meeting. ABTCP. SAo Paulo, Brazil, November 4-8, 1996

6) Basta, J., Wäne, G., Herstad Svärd, S., Jour, P. : "Comparative characterisation of the bleach plant effluents from modern ECF bleaching- eucalyptus and softwood pulps". 30 th Pulp \& Paper Annual Meeting. ABTCP, SÂo Paulo, Brazil, November 3-7, 1997

7) Basta, J., Wäne, G., Herstad Svärd, S., Lundgren, P., Johansson, N., Edwards, L., Gu, Y. : "Partial closure in modern bleaching sequences". 1996, Tappi International Pulp Bleaching Conference. Washington, p 341

8) Renberg, L. : "The use of cost-efficient chemical and biological tests for the estimation of environmental impact of bleaching plant effluents". 1992 Tappi International Environmental Conference, April 1992, p 317

9) Strömberg, L., Mörck, R., de Sousa, F., Dahlman, 0. : "Effects of internal process changes and external treatment on effluent chemistry". 2 nd International Conference on Environmental Fate and Effects of Pulp and Paper Mill Effluents, November 1994, p 3-19 


\title{
$\mathrm{ECF}$ 化に適した $\mathrm{SAQ}{ }^{\circledR}$ 蒸解について
}

\author{
川崎化成工業株式会社 技術研究所 田中 潤治
}

蒸解助剂 $\mathrm{SAQ}{ }^{\otimes}$ は, “キノン蒸解”の名で広く知られた薬刜であり, 数多くの KP 工場で長年にわた クご使用頂いている。本稿では，この $\mathrm{SAQ}{ }^{\circledR} \mathrm{ECF}$ 漂白導入に祭して，より有効に活用するという新 たな用途を提言している。まず，SAQ ${ }^{\circledR}$ 使用することにより，パルプ歩留と強度を保持した状態でカ ッパー洒を下げ，漂白負荷を軽滅するという効果について述べる。また，スラリー型アントラキノン(通

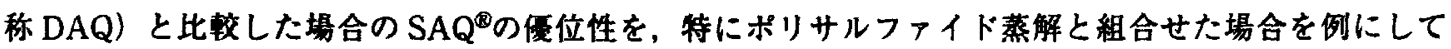
説明する。最後に，改良蒸解技術への当社の取り組みについても述べる。

(本文1ページ)

\section{$\mathrm{ECF}$ 漂白での $\mathrm{N}$ 材パルプとユーカリパルプの比較}

$$
\begin{array}{ll}
\text { エカケミカルス株式会社 } & \text { レナート・ミューラー, ジリ・バスタ, } \\
& \text { リレモア・ホルティンジャー, ゲルト・ヴェーン }
\end{array}
$$

この報文では ECF 漂白及び排水性状について $\mathrm{N}$ 材パルプとユーカリパルプとを比較する。検討は酸 素を使用しないバルフ及び酸素で前処理したパルプの両方について行った。

ECF 漂白の最䔔化の検討ではすべてのパルブについて 5 段シーケンスを使用し，また排水性状の検 討でも同様の漂白シーケンスを使用した。但し酸素で前処理したユーカリパルプについては 3 段シーヶ ンスで漂白した。さらに全ての漂白段からの排水を全部一緒にした排水（コンバインド排水）の生化学 処理を行い処理前後の性状を調べた。

$\mathrm{N}$ 材及びユーカリの酸素を使用しないパルブ及び酸素で前処理したパルブを 5 段シーケンスで $89 \%$ ISO 以上の白色度で漂白できた。最適漂白条件についてはN 材及びユーカリの酸素を使用しないパル プ及ひ酸素で前処理したパルブ共に明らかな類似性がある。

$\mathrm{COD}$ の主要成分である，リクニン，炭水化物，メタノール，低分子の酸及び抽出物，の外部処理前 後の性状は全有機成分の計算值とよく一致した。その結果, 排水中の有機成分はパルプの種類によって 変動することがわかった。 $\mathrm{N}$ 材パルブ排水中のリダニン湦度はスーカリパルブ排水と比較して相当高い。 $\mathrm{N}$ 材パルブ排水では排水処理での COD 減少率が低い。これは生化学処理ではリグニンがほとんど分解 されないからである。

生化学処理によりステロールと樹脂酸はほほ全量除去されるから生化学処理後の排水の Microtox,Selenastrum, 及び Ceriodaphnia Dubia による生物検定での反応は見られなかった。

(本文 8 ページ) 